\title{
Electrocatalytic Behaviour of Nickel-Cerium Alloy Deposits
}

\author{
A. Subramania, ${ }^{\mathrm{a},{ }^{*}}$ A.R.S. Priya ${ }^{\mathrm{a}}$ and V.S. Muralidharan ${ }^{\mathrm{b}}$ \\ a) Advanced Materials Research Lab, Department of Industrial Chemistry, Alagappa \\ University, Karaikudi - 630003, India \\ ${ }^{b)}$ Central Electrochemical Research Institute, Karaikudi- 630 006, India
}

Received 22 January 2007; accepted 20 July 2007

\begin{abstract}
Electrodeposition of Ni-Ce alloy on steel was studied and an electroplating bath was optimized for maximum cathodic current efficiency. Cerium sulphate content in the bath decreased the cathodic current efficiency. Hydrogen evolution reaction from $\mathrm{NaOH}$ solution was catalysed by cerium in the alloy and also the increase of cerium content increased the catalytic activity. Among the various $\mathrm{Ni}-\mathrm{Ce}$ alloys, $\mathrm{Ni}_{77} \mathrm{Ce}_{23}$ alloy offered the maximum catalytic activity.
\end{abstract}

Keywords: electrodeposition, $\mathrm{Ni}-\mathrm{Ce}$ alloy, electrocatalysis, $\mathrm{NaOH}$, hydrogen evolution reaction.

\section{Introduction}

Hydrogen as an ideal energy storage medium has attracted worldwide interest, as it is a clean and fully recyclable substance with a practically unlimited supply $[1,2]$. The hydrogen energy system consists mainly of three processes: the production, transport or storage and utilization of hydrogen. Large-scale, cheap production of hydrogen is a key link in the course of developing a novel hydrogen energy system. The electrocatalysis of water is an ideal method for large-scale production of hydrogen. However, lowering the electrolytic energy consumption is needed in order to make the method economically practicable. One of the most effective ways of minimizing the energy consumption is to reduce the hydrogen evolution overpotential of the cathode in the electrolysis process. Therefore, the development of highly active and durable electrode materials as hydrogen cathodes is significant in the hydrogen energy system and electrocatalysis industry.

In this direction, many investigations on the catalytic activities of nickel based alloys have been made to use as electrode materials for hydrogen evolution

\footnotetext{
* Corresponding author. E-mail address: a_subramania@gmail.com.
} 
reaction [3-5]. Porous and solid nickel alloys offered lower hydrogen overpotentials [6,7]. In this paper, an attempt has been made for the first time to develop an electrodeposit of Ni-Ce alloys for electrocatalytic purposes. This paper deals with the electroplating bath development and characterization of $\mathrm{Ni}$ Ce alloy deposits for hydrogen evolution reaction.

\section{Experimental details}

Cold rolled steel plates $(10 \times 7.5 \times 0.05 \mathrm{~cm})$ were degreased with trichloroethylene and alkaline electrocleaned cathodically for 2 minutes in a solution composed of $35 \mathrm{gpl} \mathrm{NaOH}$ and $25 \mathrm{gpl} \mathrm{Na}_{2} \mathrm{CO}_{3}$ at $70{ }^{\circ} \mathrm{C}$; they were washed in running water and then dipped for 10 seconds in $5 \% \mathrm{H}_{2} \mathrm{SO}_{4}$ solution. Finally thorough washing and drying were carried out. A hull cell was employed to assess and optimise the conditions for the production of good electrodeposits. A cell current of $1 \mathrm{~A}$ was used for 10 minutes. A regulated power supply was used as direct current source and a calibrated ammeter along with the cell constituted the electrical circuit.

For current efficiency experiments, the electrodeposition assembly comprised of platinum as anode and mild steel as cathode of equal size $(10 \times 7.5 \times 0.05 \mathrm{~cm})$ immersed in plating bath and the plating bath was agitated and heated (if needed) using a heater cum magnetic stirrer. For current efficiency determination, each specimen was weighed before and after plating and the weight of the deposit was found from the difference:

Cathodic current efficiency $(\%)=\frac{\text { Weight of the metal deposited }}{\text { Theoretical weight obtained from Faraday's law }} x 100$

The cathodic current efficiency of the alloy is calculated as:

Cathodic current efficiency $(\%)=\frac{\mathrm{M} .100}{\mathrm{e}_{\text {alloy }} Q}$

where $\mathrm{M}$ is the mass of the alloy deposit $(\mathrm{g}), \mathrm{e}_{\text {alloy }}$ is the electrochemical equivalent of the alloy and $\mathrm{Q}$ is the quantity of electricity passed $(\mathrm{A} / \mathrm{sec})$.

The electrochemical equivalent of the alloy was calculated as

$\mathrm{e}_{\text {alloy }}=\mathrm{e}_{\mathrm{Ni}} \times \mathrm{e}_{\mathrm{Ce}} /\left(\left(\mathrm{e}_{\mathrm{Ni}} \mathrm{f}_{\mathrm{Ce}}\right)+\left(\mathrm{e}_{\mathrm{Ce}} \mathrm{f}_{\mathrm{Ni}}\right)\right)$

where $e_{\mathrm{Ni}}$ and $\mathrm{e}_{\mathrm{ce}}$ are the electrochemical equivalents of the constituent metals and $\mathrm{f}_{\mathrm{Ni}}$ and $\mathrm{f}_{\mathrm{ce}}$ are the fractions in the deposits.

The density of the alloy was calculated by taking into consideration the fraction of the constituent metals. The electrodeposits were removed chemically by immersion in 1:1 $\mathrm{HNO}_{3}$ and the resultant solutions containing nickel and cerium were analyzed by atomic absorption spectroscopy. The amount of cerium in the deposit was calculated from the difference in the total mass of the deposit and the amount of nickel determined.

To understand the electrocatalytic activity of Ni-Ce alloy deposits, electrochemical polarization measurements were carried out using EG \& G - 
electrochemical analyzer (model 6310) at a scan rate of $1 \mathrm{mV} \mathrm{s}^{-1}$ in $1 \mathrm{M} \mathrm{NaOH}$ for hydrogen evolution reaction using three electrode glass cell. The Ni-Ce deposit coated on mild steel specimen of $1 \mathrm{~cm}^{2}$ area was used as working electrode. The platinum foil and $\mathrm{Hg} / \mathrm{HgO} / \mathrm{OH}^{-}$electrode were used as counter and reference electrodes, respectively.

Impedance measurements were carried out using EG \& G - electrochemical impedance analyzer (model 6310) for different compositions of $\mathrm{Ni}-\mathrm{Ce}$ alloy deposits in $1 \mathrm{M} \mathrm{NaOH}$ solution at $298 \mathrm{~K}$ using a three electrode glass cell. The working electrode was dipped in $1 \mathrm{M} \mathrm{NaOH}$ for 5-10 minutes and allowed to attain the steady state potential. The experiments were made in the frequency range of $100 \mathrm{kHz}$ to $10 \mathrm{mHz}$ with a $10 \mathrm{mV}$ sinusoidal perturbation. Impedance spectra were recorded at a cathode over potential of $250 \mathrm{mV}$ in the hydrogen evolution reaction region.

\section{Results}

Electrodeposition of $\mathrm{Ni}$-Ce alloy

The Ni-Ce alloy was deposited from sulphate bath. The influence of current density, time duration, $\mathrm{pH}$ and concentration of cerium ions on the electrodeposit were studied. Fig. 1 presents the code used to express Hull cell patterns. Fig. 2a depicts the Hull cell pattern obtained from the Watt's nickel plating bath (nickel sulphate $240 \mathrm{gpl}$; nickel chloride $20 \mathrm{gpl}$ and boric acid $40 \mathrm{gpl}$ ) at $303 \mathrm{~K}$. Addition of $0.2 \mathrm{gpl}$ of sodium lauryl sulphate (SLS) and $0.2 \mathrm{gpl}$ of saccharin (Fig. 2b) revealed that the bright deposition range increased. In presence of 20 gpl cerium sulphate, the uniform bright deposit was seen up to $5 \mathrm{~A} / \mathrm{dm}^{2}$.
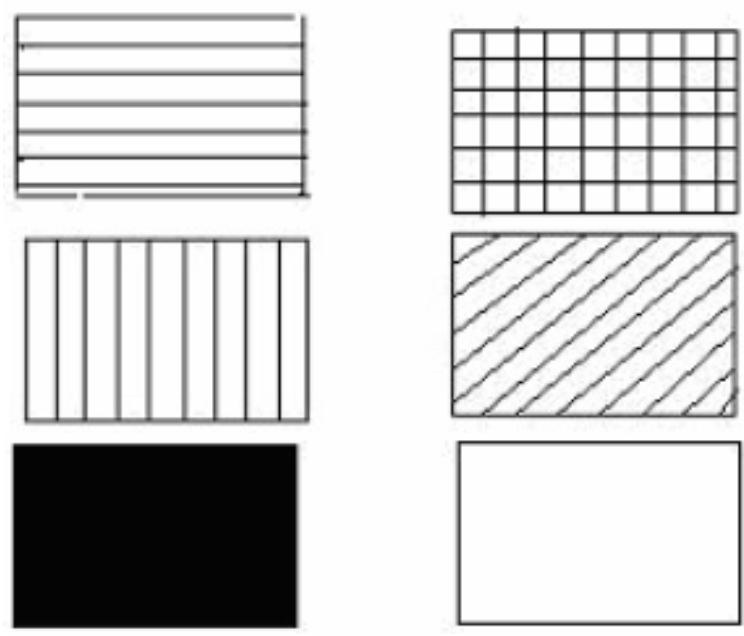

Figure 1. Code for recording the Hull cell pattern. 

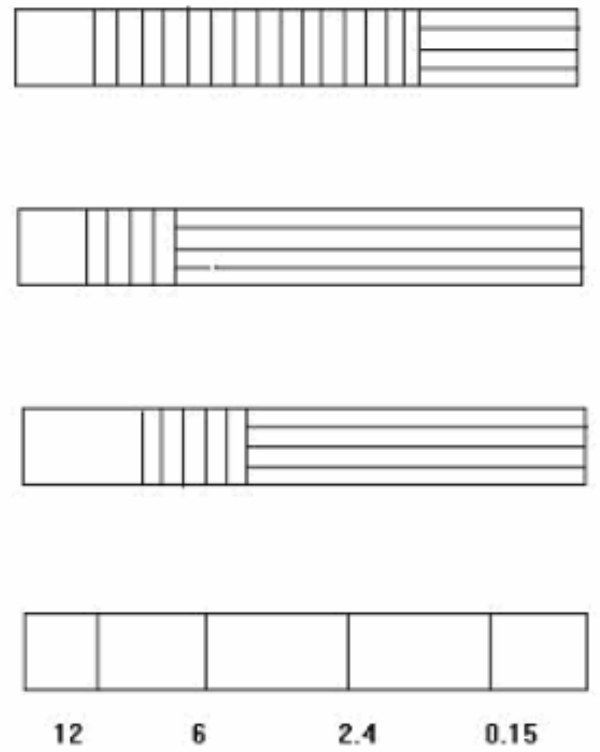

Figure 2. Hull cell patterns for Ni-Ce bath.

The cathodic current efficiency (C.C.E \%) increased up to $7 \mathrm{~A} / \mathrm{dm}^{2}$ while $\%$ of cerium in the deposit increased with current density (Table 1). The cathodic current efficiency (\%) decreased with $\mathrm{CeSO}_{4}$ concentration while $\%$ of cerium in the alloy increased (Table 2). The effect of $\mathrm{pH}$ decreased the C.C.E (\%) and \% of cerium in the alloy increased up to $\mathrm{pH} 4.5$ and then decreased (Table 3). C.C.E. and $\%$ of cerium in the alloy increased with temperature up to $323 \mathrm{~K}$ and then decreased (Table 4).

Table 1. Effect of current efficiency on \% CCE and \% Ce in the alloy deposits.

\begin{tabular}{|c|c|c|}
\hline $\begin{array}{c}\text { Current density } \\
\left(\mathrm{A} / \mathrm{dm}^{2}\right)\end{array}$ & $\begin{array}{c}\text { CCE } \\
(\%)\end{array}$ & $\begin{array}{c}\text { \% Ce in the } \\
\text { alloy deposits }\end{array}$ \\
\hline 3 & 71.5 & 18.0 \\
5 & 80.0 & 23.5 \\
7 & 78.0 & 28.0 \\
9 & 75.0 & 28.5 \\
\hline
\end{tabular}

Table 2. Effect of cerium sulphate on $\% \mathrm{CCE}$ and $\% \mathrm{Ce}$ in the alloy deposits.

\begin{tabular}{|c|c|c|}
\hline $\begin{array}{c}\text { Conc. of } \\
\begin{array}{c}\mathrm{CeSO}_{4} \\
(\mathrm{~g} / \mathrm{L})\end{array}\end{array}$ & $\begin{array}{c}\mathrm{CCE} \\
(\%)\end{array}$ & $\begin{array}{c}\text { \% Ce in the } \\
\text { alloy deposits }\end{array}$ \\
\hline 5 & 80 & 12.5 \\
10 & 78 & 16.0 \\
15 & 76 & 18.0 \\
20 & 71.75 & 23.5 \\
\hline
\end{tabular}


Table 3. Effect of $\mathrm{pH}$ on $\% \mathrm{CCE}$ and $\% \mathrm{Ce}$ in the alloy deposits.

\begin{tabular}{|c|c|c|}
\hline $\mathrm{pH}$ & $\begin{array}{c}\mathrm{CCE} \\
(\%)\end{array}$ & $\begin{array}{c}\text { \% Ce in the } \\
\text { alloy deposits }\end{array}$ \\
\hline 3 & 70 & 17.5 \\
4 & 80 & 22.5 \\
5 & 78.5 & 22.0 \\
6 & 67.5 & 20.0 \\
\hline
\end{tabular}

Table 4. Effect of temperature on \% CCE and \% Ce in the alloy deposits.

\begin{tabular}{|c|c|c|}
\hline $\begin{array}{c}\text { Temperature } \\
(\mathrm{K})\end{array}$ & $\begin{array}{c}\text { CCE } \\
(\%)\end{array}$ & $\begin{array}{c}\text { \% Ce in the } \\
\text { alloy deposits }\end{array}$ \\
\hline 303 & 71 & 16.5 \\
313 & 74 & 23.5 \\
323 & 80 & 24.0 \\
333 & 76.5 & 18.0 \\
\hline
\end{tabular}

\section{Electrocatalysis}

Four Nickel-Cerium alloy deposits were used to study the hydrogen evolution reaction in $1 \mathrm{M} \mathrm{NaOH}$ solution. Fig. 3 presents the anodic and cathodic polarization curves for various alloy deposits.

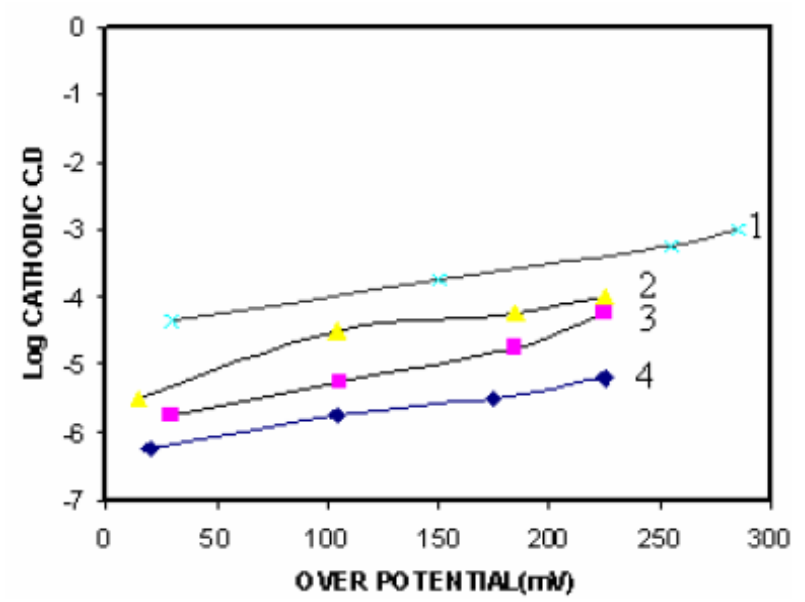

Figure 3. Potentiodynamic polarization curves obtained in $1 \mathrm{M} \mathrm{NaOH}$ solution at $323 \mathrm{~K}$ for various compositions of $\mathrm{Ni}-\mathrm{Ce}$ alloy deposits: (1) $\mathrm{Ni}_{87} \mathrm{Ce}_{13}$, (2) $\mathrm{Ni}_{84} \mathrm{Ce}_{16}$, (3) $\mathrm{Ni}_{82} \mathrm{Ce}_{18},(4) \mathrm{Ni}_{77} \mathrm{Ce}_{23}$.

Anodic Tafel slopes varied $65 \pm 8 \mathrm{mV} /$ decade for the four alloys while cathodic Tafel slopes were found to be $130 \pm 13 \mathrm{mV} /$ decade. The equilibrium potential for hydrogen evolution reaction in $1 \mathrm{M} \mathrm{NaOH}$ was calculated and the exchange current density for hydrogen evolution reaction was also calculated. Increase of cerium content in the alloy increased the exchange current density (Table 5).

Nyquist plots obtained in $1 \mathrm{M} \mathrm{NaOH}$ at a cathodic over potential of $250 \mathrm{mV}$ are shown in Fig. 4(a-d). The charge transfer resistance decreased while the double 
layer capacitance value increased, suggesting that the increase of cerium in the alloy increased the hydrogen evolution reaction rate (Table 6).

Table 5. Tafel slopes and exchange current density for the HER on different compositions of alloy deposits at $323 \mathrm{~K}$.

\begin{tabular}{|c|c|c|c|}
\hline \multirow{2}{*}{$\begin{array}{l}\text { Composition of } \\
\text { alloy deposits }\end{array}$} & \multicolumn{2}{|c|}{$\begin{array}{l}\text { Tafel slopes } \\
\text { ( mV/decade) }\end{array}$} & \multirow{2}{*}{$\begin{array}{c}\mathrm{i}_{o}, \mathrm{H}^{2} \\
\left(\mathrm{~A} / \mathrm{cm}^{2}\right)\end{array}$} \\
\hline & anodic & cathodic & \\
\hline $\mathrm{Ni}_{87} \mathrm{Ce}_{13}$ & 83 & 143 & 5.6 \\
\hline $\mathrm{Ni}_{84} \mathrm{Ce}_{16}$ & 75 & 136 & 8.7 \\
\hline $\mathrm{Ni}_{82} \mathrm{Ce}_{18}$ & 66 & 130 & 22.0 \\
\hline $\mathrm{Ni}_{97} \mathrm{Ce}_{23}$ & 63 & 122 & 45.0 \\
\hline
\end{tabular}

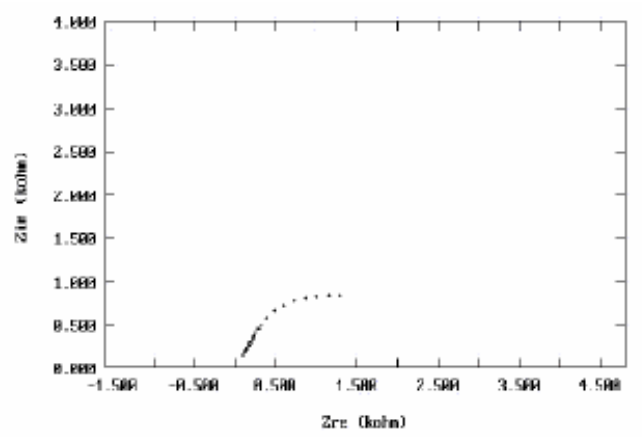

(a)

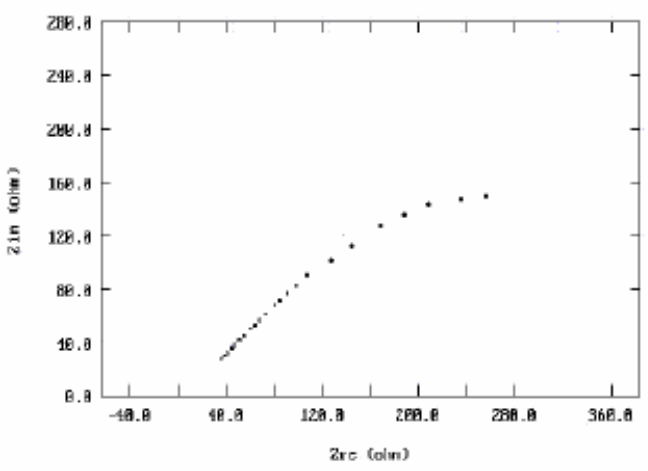

(c)

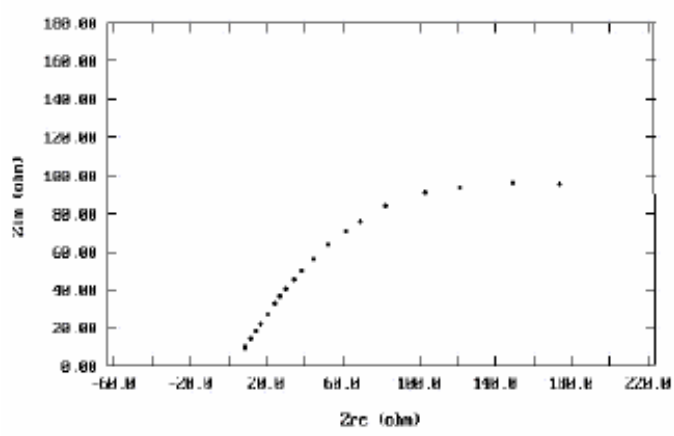

(b)

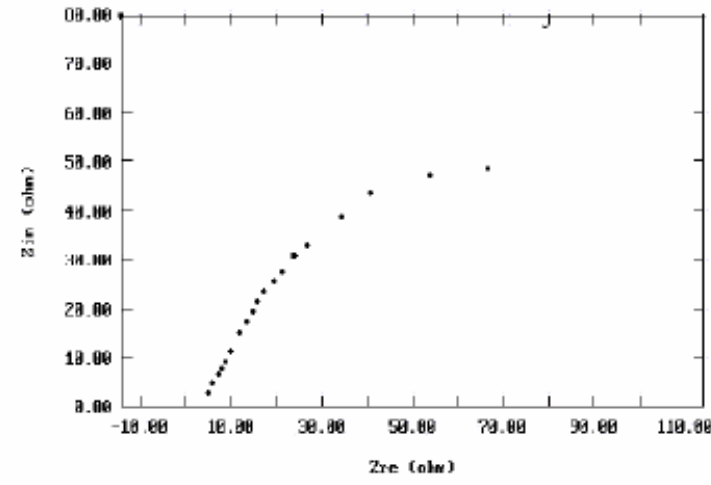

(d)

Figure 4. Nyquist plots for different compositions of alloy in $1 \mathrm{M} \mathrm{NaOH}$ solution at a cathodic polarization of $250 \mathrm{mV}$. (1) $\mathrm{Ni}_{87} \mathrm{Ce}_{13}$, (2) $\mathrm{Ni}_{84} \mathrm{Ce}_{16}$, (3) $\mathrm{Ni}_{82} \mathrm{Ce}_{18}$, (4) $\mathrm{Ni}_{77} \mathrm{Ce}_{23}$.

Table 6. Impedance parameters derived from Nyquist plots at a cathodic over potential of $250 \mathrm{mV}$ at $323 \mathrm{~K}$.

\begin{tabular}{|c|c|c|}
\hline $\begin{array}{c}\text { Composition of } \\
\text { alloy deposits }\end{array}$ & $\begin{array}{c}\mathrm{R}_{\mathrm{ct}} \\
\left(\mathrm{ohm} . \mathrm{cm}^{2}\right)\end{array}$ & $\begin{array}{c}\mathrm{C}_{\mathrm{dL}} \\
\left(\mu \mathrm{F} / \mathrm{cm}^{2}\right)\end{array}$ \\
\hline $\mathrm{Ni}_{87} \mathrm{Ce}_{13}$ & 3500 & 390 \\
$\mathrm{Ni}_{84} \mathrm{Ce}_{16}$ & 600 & 240 \\
$\mathrm{Ni}_{82} \mathrm{Ce}_{18}$ & 360 & 1100 \\
$\mathrm{Ni}_{77} \mathrm{Ce}_{23}$ & 180 & 2500 \\
\hline
\end{tabular}




\section{Discussion}

From uncomplexing solutions the deposition of nickel in the acidic $\mathrm{pH}$ range was found to occur [6] as

$$
\begin{aligned}
& \mathrm{H}_{2} \mathrm{O}+2 \mathrm{e} \longrightarrow \mathrm{H}_{2}+\mathrm{OH}^{-} \\
& \mathrm{Ni}^{2+}+\mathrm{OH}^{-} \longrightarrow \mathrm{NiOH}^{+} \\
& \mathrm{NiOH}^{+}+\mathrm{e} \longrightarrow \mathrm{NiOH} \text { ads } \\
& \mathrm{NiOH}+\mathrm{e} \longrightarrow \mathrm{Ni}+\mathrm{OH}^{-}
\end{aligned}
$$

In presence of nickel, cerium gets deposited as

$$
\begin{aligned}
\mathrm{Ce}^{2+}+\mathrm{OH}^{-} & \longrightarrow \mathrm{CeOH}^{+} \\
\mathrm{CeOH}^{+}+\mathrm{e} & \longrightarrow \mathrm{Ce}+\mathrm{OH}^{-}
\end{aligned}
$$

Increase of cerium content in the alloy favoured HER from plating solution and hence C.C.E \% decreased with $\mathrm{CeSO}_{4}$ concentration.

Hydrogen evolution reaction in alkaline solution proceeds via

1. electronation of water with adsorption of hydrogen (Volmer reaction);

2. electrochemical desorption of $\mathrm{H}_{2}$ (Heyrovsky reaction);

3. chemical desorption (Tafel reaction).

$$
\begin{aligned}
& \mathrm{M}+\mathrm{H}_{2} \mathrm{O}+\mathrm{e} \leftrightarrow \mathrm{MH}_{\mathrm{ads}}+\mathrm{OH}^{-} \\
& \mathrm{MH}_{\mathrm{ads}}+\mathrm{H}_{2} \mathrm{O}+\mathrm{e} \leftrightarrow \mathrm{M}+\mathrm{H}_{2}+\mathrm{OH}^{-} \\
& 2 \mathrm{MH}_{\mathrm{ads}} \leftrightarrow \quad 2 \mathrm{M}+\mathrm{H}_{2} \uparrow
\end{aligned}
$$

If the adsorption of atomic hydrogen obeys Langmuir isotherm and $\theta \rightarrow 1$, then electrochemical desorption mechanism, i.e., a fast Volmer reaction following a slow Heyrovsky reaction, would result $(\mathrm{d} \eta / \mathrm{dpH})=0$. The observed value confirms this.

In order to correlate $\mathrm{M}-\mathrm{H}$ bond energy and exchange current density, various ideas like "Volcano" shaped curves were suggested [7,8]. As HER involves the transfer of the electron from an electrode surface (work function), the density of states of electrons close to the energy level of metal surface (density of states at $\mathrm{E}_{\mathrm{F}}$ ) is an important parameter governing electrochemical reaction rates. The electron density of states at $\mathrm{E}_{\mathrm{F}}$ may be increased by forming substitution alloys and inter metallic phases to improve the catalytic activity. In the present study, increase of $\mathrm{Ce}$ content in the alloy increased the hydrogen evolution reaction.

\section{Conclusions}

The Ni-Ce alloy electrodeposition bath after optimization has $\mathrm{NiSO}_{4} 240 \mathrm{gpl}$, $\mathrm{NiCl}_{2} 20 \mathrm{gpl}$, boric acid $40 \mathrm{gpl}, \mathrm{CeSO}_{4} 20 \mathrm{gpl}$ at $5 \mathrm{~A} / \mathrm{dm}^{2}$ in the $\mathrm{pH}$ range 4 to 5 at 313 to $323 \mathrm{~K}$. The presence of cerium content in the alloy deposit enhanced the hydrogen evolution reaction. Among the various compositions of $\mathrm{Ni}-\mathrm{Ce}$ alloys, $\mathrm{Ni}_{77} \mathrm{Cl}_{23}$ alloy electrodeposit offered maximum electrocatalytic activity. 


\section{References}

1. W. Hu, Y. Zhang, D. Song, Z. Zhou and Y. Wang, Mater. Chem. Phys. 41 (1995) 141.

2. W.E. Winsche, K.C. Hoffman and F.J. Salzano, Science 180 (1973) 1325.

3. P. Gu, L. Bai, L. Gao, R. Brousseau and B.E. Conway, Electrochim. Acta 37 (1992) 2145.

4. N.A. Assuncao, M.J. Degiz, G. Tremillosi and E.R. Gonzales, J. Electrochem. Soc. 144 (1997) 2794.

5. H. Schimdt and H. Wendt, Electrochim. Acta 40 (1995) 1663.

6. I. Paseka, Electrochim. Acta 40 (1995) 1663.

7. $\quad$ N. Yoshida and Morimoto, Electrochim. Acta 39 (1994) 1733.

8 V.S. Muralidharan, M. Veerashunmugamani, G.P. Kalaignan and S. Arulraj, Bull. Electrochem. 1 (1985) 241.

9. S. Trasatti, J. Electroanal. Chem. 39 (1972) 163.

10. S. Trasatti, Electrochim. Acta. 39 (1994) 1739. 